\title{
TATA KELOLA HUMAS PEMERINTAH DAERAH KABUPATEN SAMPANG MADURA
}

\author{
Bani Eka Dartiningsih \\ Dosen Program Studi Ilmu Komunikasi \\ bani.eka@trunojoyo.ac.id
}

\begin{abstract}
ABSTRAK
Humas adalah suatu bentuk komunikasi yang berlaku bagi semua jenis organisasi, baik komersial maupun non komerisal. Humas merupakan profesi yang menghubungkan antara lembaga atau organisasi dan publik yang ikut menentukan kelangsungan hidup lembaga. Oleh karena itu, humas berfungsi menumbuhkan hubungan baik antara segenap komponen, memberikan pengertian, menumbuhkan motivasi, dan partisipasi. Humas pada dasarnya menciptakan kerja sama berdasarkan hubungan baik dengan publik.

Dalam konteks lembaga-lembaga publik seperti pemerintah, peran melayani dan mengembangkan dukungan publik untuk mencapai tujuan organisasilah yang sangat pentingdimainkan oleh praktisi kehumasan. Pada konteks ini praktisi humas harus bisa membentuk nilai-nilai, pemahaman, sikapsikap, sampai perilaku dari publik agar sejalan dengan kebutuhan organisasi
\end{abstract}

Keywords: Humas pemerintah,

\section{PENDAHULUAN.}

Dalam rangka mewujudkan tata kelola pemerintahan yang baik, dilakukan pembangunan aparatur negara melalui reformasi birokrasi untuk meningkatkan profesionalisme aparatur negara di pusat dan daerah. Revitalisasi kehumasan dengan tujuan peningkatan profesionalisme hubungan masyarakat (humas) sebagai ujung tombak pengelolaan informasi, dibangun melalui peningkatan kapasitas dan kompetensi sumber daya manusia (SDM), penguatan struktur dan infrastruktur, sistem dan prosedur, komunikasi organisasi, serta manajemen komunikasi krisis, dalam upaya menciptakan tata kelola pemerintahan yang baik.

Salah satu pihak yang memegang peranan penting dalam implementasi keter- bukaan informasi adalah humas pemerintah yang berkewajiban menyediakan informasi kepada masyarakat. Pemahaman akan pentingnya keberadaan humas dalam sebuah perusahaan atau organisasi terus berkembang pesat, meskipun belum ada standarisasi yang jelas dan baku bagi mereka yang akan menggeluti dunia profesi Humas. Banyaknya definisi dari kata Humas menjadikan banyak pula pemahaman atau persepsi yang berbeda-beda mengenai humas. Namun dibalik kenyataan tersebut. Padahal profesi ini sudah berkembang seiring peningkatan pemahaman dan pengakuan masyarakat.

Gambaran profesi Humas yang asal cantik, apalagi seorang public figure (artis atau model) masih dianut oleh beberapa perusahaan atau organisasi. Dengan bermodalkan itu, direkrutlah ia menjadi seorang 
praktisi Humas. Padahal banyak kriteria yang harus dimiliki seseorang yang akan bergerak sebagai praktisi humas suatu perusahaan, atau konsultan humas. Menurut Frank Jefkins, kriterianya adalah Ability to communicate, ability to organize, ability to get on with people, personality integrity dan imagination. Keberadaan Humas berfungsi sebagai mediator yang menjembatani kepentingan organisasi atau perusahaan dengan publiknya. Sehingga berbagai aktivitas senantiasa menciptakan, menjaga dan meningkatkan citra atau image yang positif.

F. Rachmadi dalam bukunya Public Relations dalam teori dan praktek menyebutkan bahwa masalah penting yang dihadapi lembaga-lembaga ekonomi, bisnis, sosial, dan politik setelah terjadinya revolusi industri adalah masalah hubungan. Ketergantungan antar individu dengan peru-sahaan, dan pemerintah dengan organisasi-organisasi sosial dan masyarakat telah menciptakan kebutuhan akan filsafat dan fungsi baru dalam manajemen. Fungsi itulah yang disebut sebagai Hubungan Masyarakat (PR), dan untuk itulah humas ada. (Rachmadi, 1996:59)

Humas harus memiliki sifat membina dan mengembangkan partisipasi masyarakat. Di era reformasi yang menuntut segala sesuatunya serba transparan, juga berdampak terhadap keingintahuan masyarakat akan berbagai informasi yang berkenaan dengan penyelenggaraan pemerintahan dan pembangunan.

Pemerintah di tuntut menyediakan informasi dan mengkomunikasikan/mensosialisasikannya sesuai dengan keinginan masyarakat, sebab pada dasarnya pemerintah adalah pelayan masyarakat (public service) yang harus memberikan pelayan dan mengabdi kepada masyarakat. Memberikan pelayanan kepada masyarakat merupakan tugas utama pemerintah. Pelayanan yang diberikan harus dilakukan sebaik mungkin sehingga tercipta hubungan yang harmonis antara pemerintah dengan masyarakat. Disini-lah diperlukan peran humas pemerintah untuk mensosialisasikan kebijakan tersebut kepada masyarakat.

Humas Pemerintah Kabupaten Sampang Madura bekerja sama dengan berbagai publik terutama media untuk mempermudah dan menunjang kegiatan sosialisasi kebijakan atau Perda. Sehingga masyarakat mendapat kejelasan tentang hak dan kewajibannya terhadap pemberlakuan kebijakan atau perda tersebut. Layanan yang bercirikan cepat, tepat, baik, dan akurat mutlak harus diberikan kepada masyarakat. Karena kualitas layanan sangat mempengaruhi kepercayaan masyarakat terhadap kredibilitas pemerintahnya. Setiap kali ada peraturan, undang-undang, atau kebijakan pemerintah yang mempengaruhi nasib masyarakat maka pihak pemerintah berkewajiban berusaha untuk menjelaskan berbagai implikasinya kepada segenap masyarakat, karena nasib merekapun turut terpengaruh.

Dalam konteks Pemerintah Kabupaten Sampang, Humas memiliki peran sebagai juru bicara pemda, mempublikasikan tentang keunggulan daerahnya meliputi pembangunan pemerintah serta mendokumentasikan segala bentuk kegiatan yang berkaitan dengan pemerintah dan pembangunan di Kabupaten 
Sampang. Tidak hanya itu saja, humas juga berperan sebagai mitra pencitraan good goverment dengan media massa sehingga jalinan kerjasama antara pemerintah yang diwakili oleh Humas dengan media massa berjalan dengan baik dalam rangka memberikan informasi kepada khalayak ramai.

\section{Humas Pemerintah}

Peranan humas di lingkungan pemerintah sangat penting dalam membangun citra positif, apalagi dewasa ini pemerintah tengah menghadapi persoalan kemasyarakatan yang mendasar, yakni peningkatan investasi guna mengurangi kemiskinan dan pengangguran. Hadirnya jembatan Suramadu memberi warna baru bagi masyarakat Madura. Diharapkan masyarakat Madura mampu memanfaatkan fasilitas serta berkreasi dengan memanfaatkasn potensinya. Hadirnya jembatan Suramadu memungkinkan munculnya pusat-pusat industri baru di Madura. Pemerintah daerah dewasa ini dituntut untuk dapat memberikan pelayanan publik yang lebih efektif.

Pada saat ini banyak dipraktekkan di berbagai organisasi dalam rangka menunjang organisasi untuk mencapai tujuannya secara efektif dan efisien. Pelaksanaan PR dalam organisasi atau perusahaan dititikberatkan pada keterampilan membina hubungan antar manusia di dalam organisasi untuk mengatasi timbulnya masalah. Public relations sendiri mempunyai dua pengertian yaitu :

- Public relations sebagai method of communication yaitu merupakan rangkaian kegiatan atau sistem kegiatan yaitu kegiatan berkomunikasi secara khas .
- Public relations sebagai state of being yaitu perwujudan kegiatan komunikasi (Effendi, 1989 : 94 ).

L. Roy Blumenthal dalam bukunya The Practice of Public Relations yang dikutip oleh Effendy mengatakan sebagai berikut: "Seni membina pribadi seseorang hingga taraf yang memungkinkan ia mampu menghadapi keadaan darurat dalam kehidupan sehari-hari termasuk dalam bidang psikologi,seni melaksanakan tugas yang sama untuk bisnis, lembaga, pemerintah, baik yang menimbulkan keuntungan atau yang tidak, termasuk public relations" (Effendi, 1989: 94-95 ). Dalam pengertian diatas dapat disimpulkan bahwa PR hanyalah terdapat dalam suatu organisasi yang jelas strukturnya serta jelas adanya pemimpin dan yang dipimpin tetapi dalam suatu organisasi yang tidak dilengkapi dengan bagian PR, tidak berarti tidak ada kegiatan kehumasan. Seluruh anggota organisasilah yang melaksanakan kegiatan kehumasan.

Sebagai metode komunikasi mempunyai makna bahwa setiap pemimpin dari suatu organisasi, bagaimanapun kecilnya dapat melaksanakan PR, suatu kegiatan komunikasi yang khas mempunyai ciri-ciri dan meliputi aspek-aspeksebagai berikut :

- $\quad$ komunikasi yang dilaksanakan berlangsung dua arah secara timbal balik

- Kegiatan yang dilakukan terdiri atas penyebaran informasi, pelaksanaan persuasi dan pengkajian opini publik

- Tujuan yang dicapai adalah tujuan organisasi itu sendiri. 
- Sasaran yang dituju adalah publik di dalam dan publik di luar.

- Efek yang diharapkan adalah terjadinya hubungan yang harmonis antara organisasi dengan publik (Effendi, 1989: 95 ).

Landasan bagi hubungan masyarakat yang efektif ialah kebijaksanaan dan kegiatan yang terpercaya demi kepentingan publik. Komunikasi hubungan masyarakat merupakan suatu proses yang mencakup suatu pertukaran fakta, pandangan dan gagasan diantara suatu bisnis atau organisasi tanpa laba dengan publik-publiknya untuk saling pengertian. Salah satu unsur dasar PR adalah komunikasi timbal balik. Melalui komunikasi kepada publiknya, manajemen mengumumkan menjelaskan dan mempertahankan atau mempromosikan kebijaksanaannya dengan maksud untuk mengukuhkan pengertian dan penerimaan.

Dalam PR, pengertian publik ialah sekelompok orang yang sama-sama terikat dan terkait perhatiannya oleh kepentingan yang sama. Kelompok-kelompok ini harus senantiasa dihubungi dalam rangka melaksanakan fungsi PR. Pada umumnya publik-publik dari PR terbagi menjadi publik internal dan publik eksternal. Berdasarkan pengelompokkan ini maka terjadi dua hubungan yaitu hubugan internal ialah hubungan dengan karyawan dan hubungan dengan pemegang saham. Sedangkan yang kedua ialah hubungan eksternal yaitu hubungan dengan masyarakat, hubungan dengan pelanggan, hubungan dengan khalayak, dan hubungan dengan konsumen Hubungan dengan publik tersebut sangat penting dipelihara dan dibina dalam rangka mempertahankan goodwill dan kepercayaan pada publik serta dalam rangka menimbulkan pengertian bersama dan hubungan yang harmonis antara kedua belah pihak yaitu perusahan dengan konsumennya. Hubungan ini dilakukan dengan komunikasi yang meliputi berbagai teknis untuk dipilih, mana yang paling efektif. Salah satu caranya ialah dengan memanfaatkan surat kabar sebagai salah satu media dalam kegiatan PR.

\section{Masyarakat Sebagai Publik Humas Eksternal}

Eksternal publik relations merupakan hubungan tidak langsung dengan perusahaan tetapi mempegaruhi manajemen. Tujuannya ialah untuk menciptakan hubungan dalam mendapatkan opini yang favorabel (menyenangkan) dan untuk mendapatkan citra yang baik. Bagi suatu perusahaan hubunganhubungan dengan publik luar perusahaan merupakan suatu keharusan di dalam usaha untuk :

1. Memperoleh langganan.

2. Memperkenalkan produksi.

3. Mencari modal dan keuntungan.

4. Memperbaiki hubungan dengan masyarakat luar dan serikat buruh yang ada di luar perusahaan.

5. Memecahkan persoalan yang dihadapi (Abdurrachman, 1995: 38 )

Salah satu publik eksternal adalah masyarakat. Untuk dapat membentuk hubungan yang baik dengan masyarakat, maka praktisi PR harus meneliti masyarakat 
yang akan dijadikan publik dari organisasi atau instansi atau perusahaan tersebut dengan berkomunikasi dengan organisasi yang tidak melakukan komunikasi dengan publiknya maka publik tersebut secara aktif akan berusaha mencari informasi dan menyimpan informasi yang dapat mempertegas sikap dan perilaku yang dipilahnya.

\section{Revitalisasi Humas Pemerintah Daerah Kabupaten Sampang}

Upaya revitalisasi peranan kehumasan sangat penting dan menjadi tuntutan yang mendesak saat ini, wajib dilaksanakan di semua instansi pemerintah, sebagai momentum strategis untuk melakukan perubahan tatanan peranan kehumasan yang dapat bersinergi secara efektif. Humas pemerintah selalu dituntut kemampuannya dalam menghadapi tantangan dan perubahan lingkungan yang sangat cepat.

Humas pemerintah pada dasarnya tidak bersifat politis. Bagian humas di institusi pemerintah dibentuk untuk mempublikasikan atau mempromosikan kebijakan-kebijakan mereka. Memberi informasi secara teratur tentang kebijakan,rencana-rencana serta hasil-hasil kerja institusi serta memberi pengertian kepada masyarakat tentang peraturan dan perundang-undangan dan segala sesuatunya yang berpengaruh terhadap kehidupan masyarakat. Selain keluar, humas pemerintah juga memungkinkan untuk memberi masukan dan saran bagi para pejabat tentang segala informasi yang diperlukan dan reaksi atau kemungkinan reaksi masyarakat akan kebijakan institusi, baik yang sedang dilaksanakan, akan dilaksanakan, ataupun yang sedang diusulkan Seiring dengan tuntutan transfaransi dari masyarakat luas sebagai publik pemerintah,manfaat humas dalam penyelenggaraan pemerintah secara umum telah diterima sejak lama.

Ada dua sisi yang melatarbelakangi perkembangan humas pemerintah yaitu: sisi pentingnya humas bagi pemerintah dan yang kedua adalah hambatan-hambatan yang dihadapi oleh humas pemerintah. Dua sisi ini pada akhirnya mengakibatkan penampilan humas pemerintah yang tersembunyi di bawah berbagai nama,tugas,wewenang dan dibiayai dari berbagai macam cara yang berbeda. Kebanyakan humas pemerintah diarahkan untuk hubungan dengan media, masalah umum, dokumentasi dan publikasi. Kegiatan-kegiatan yang biasanya ditangani oleh humas dalam rangka mensosialisasikan kebijakan pemerintah ialah mengadakan konferensi pers,membuat press release dan menyebarkannya pada media, pameranpameran, mengorganisisr pertemuan dengan masyarakat, penerangan melalui berbagai media komunikasi bagi masyarakat.

Menurut hemat penulis, sebagian besar humas pemerintah dalam pelaksanaannya tugas dan fungsinya masih banyak terkendala, dari masalah struktur dan organisasi humas, kultur/budaya kerja praktisi atau pejabat humas yang masih kurang strategis, dan belum banyak minat orang menjadi praktisi kehumasan. Setidaknya ada empat masalah utama yang harus segera dibenahi dan direvitalisasi oleh aparat humas memasuki era keterbukaan informasi publik, yaitu Sumber Daya Manusia (SDM), kelembagaan 
humas, infrastruktur pendukung kinerja dan sinergitas antar pemerintah serta satuan kerja.

\section{PENUTUP}

Humas pemerintah merupakan ujung tombak dalam menyampaikan program dan kinerja pemerintah. Humas pemerintah juga diharapkan juga diharapkan dapat meningkatkan pelayanan dan pengelolaan informasi disetiap instansinya, serta mampu mendorong partissipasi masyarakat dalam mensukseskan berbagai program pemerintah yang hasilnya dapat dinikmati oleh publik.

Humas sebagai corong atau sumber informasi, dituntut kemampuannya dalam menghadapi tantangan dan perubahan zaman yang sangat cepat terutama menghadapi perkembangan teknologi, informasi dan komunikasi. Untuk meningkatkan kemampuan, perangkat humas pemerintah daerah Kabupaten Sampang harus menguasai teknologi informasi dan komunikasi, termasuk didalamnya media sosial sehingga dapat mengetahui kebutuhan publik. Dan lebih penting lagi humas pemerintah harus menjalin sinergi dan akrab dengan wartawan, agar dapat mengontrol informasi yang disampaikan kepada publik.

\section{DAFTAR PUSTAKA}

Abdurrachman, Oemi. 1995. Dasar - Dasar Public Relations . Bandung : PT. Citra Aditya Bakti

Abdullah, Aceng. 2000. Press Relations. Bandung : PT Remaja Rosdakarya
Chaffe, Steven and Patrick, Michael. 1975. Using The Mass Media. New York : Mc Graw-Hill Book Company.

Effendy, Onong Uchjana .1986. Hubungan Masyarakat. Bandung : PT Remaja Karya

Jefkins Frank. 1996. Public Relations . Jakarta : Erlangga.

Liliweri, Alo. 1991. Memahami peran Komunikasi Massa dalam Masyarakat. Bandung : PT Citra Aditya Bakti.

Mappatoto, Andi. 1993. Siaran Pers Suatu Kiat Penulisan. Jakarta : PT Gramedia Pustaka Utama.

McQuail, Denis and dahl W Sven. 1984. Communication Models For Study of Mass Communication. New York : Longman inc.

McQuail, Denis.1991. Teori Komunikasi Massa: Suatu Pengantar. Diterjemahkan Aminuddin Ram. Jakarta : Erlangga.

Moleong J, Lexy. 1995. Metodologi Penelitian Kualitatif. Bandung: PT Remaja Rosdakarya.

Moore, Frazier. 1988 . Hubungan Masyarakat. Bandung :Remadja Karya CV.

Muhadjir, Noeng. 1996. Metode Penelitian Kualitatif. Yogyakarta : Rakesarasin.

Nazir, Moh.,Ph.D. 1983. Metode Penelitian. Jakarta: Ghalia Indonesia.

Rakhmat, Jalaludin. 1995.Metode Penelitian Komunikasi. Bandung : PT Remaja Rosda Karya.

Singarimbun, Masri dan Effendi Sofian.1989. Metode Penelitian Survai. Jakarta : PT Pustaka LP3ES.

Siswanto, Bambang. 1992. Humas Teori dan Praktek. Jakarta : Bumi Aksara 